\title{
REGIONAL DIFFERENCES IN THE INFLUENCE OF THE NORTH ATLANTIC OSCILLATION ON SEASONAL RIVER RUNOFF IN POLAND
}

\author{
DARIUSZ WRZESIŃSKI
}

Adam Mickiewicz University, Institute of Physical Geography and Environmental Planning, Poznań, Poland

Manuscript received: August 22, 2011

Revised version: September 3, 2011

\begin{abstract}
WRZESIŃSKI D., Regional differences in the influence of the North Atlantic Oscillation on seasonal river runoff in Poland. Quaestiones Geographicae 30(3), Bogucki Wydawnictwo Naukowe, Poznań, pp. 127-136, 6 Figs. ISBN 97883-62662-75-3. ISSN 0137-477X. DOI 10.2478/v10117-011-0032-y
\end{abstract}

АвSTRACT. In this paper, an analysis of monthly and seasonal runoff volumes in two stages of the North Atlantic Oscillation are presented. The analysis embraced runoff at 146 profiles located on 96 Polish rivers during the years 1951-2000. The changes in the runoff conditions of Polish rivers in the two NAO stages and their spatial diversity were determined based on the differences between runoff observed in the years of exceptionally high $\left(\mathrm{NAO}_{\mathrm{DJFM}}>2,0\right)$ and low $\left(\mathrm{NAO}_{\mathrm{DJFM}}<-2,0\right)$ values of the winter NAO index. The results of the research indicate that the influence of the North Atlantic Oscillation on the runoff of Polish rivers is diverse in terms of time and space. A classification of rivers was made in terms of the similarity of deviations of their seasonal runoff between the different $\mathrm{NAO}_{\mathrm{DJFM}}$ stages. In the classification procedure use was made of Ward's method of hierarchical grouping. In this way, five classes of the river profiles under analysis were obtained. Environmental conditions in the catchments and hydrological regime features clearly influence the regional differences in the impact of the North Atlantic Oscillation on the flow of rivers.

KeYwords: North Atlantic Oscillation; river runoff; river typology; Poland

Dariusz Wrzesiński, Department of Hydrology and Water Management, Institute of Physical Geography and Environmental Planning, Adam Mickiewicz University, ul. Dzięgielowa 27, 61-680 Poznań, Poland, e-mail:darwrze@amu.edu.pl

\section{Introduction}

Deviations of climatic elements from average levels, like those caused by changes in the atmospheric circulation, modify the conditions in which the river runoff forms. The river regime is controlled by both, precipitation and air temperature, whose values show a significant dependence on the intensity of zonal circulation. A simple indicator characterising the atmospheric circulation over the north Atlantic is the North Atlantic
Oscillation Index (henceforth, NAO). The North Atlantic Oscillation is considered a very important climate-forming factor in Poland (Marsz \& Żmudzka 1999, Marsz 2001). It has been found to be greatly responsible for temperature rise in the cold season of the year (Marsz \& Styszyńska 2001, Kożuchowski \& Degirmendžić 2002, Niedźwiedź 2002, Przybylak et al. 2003), and to have a great impact on the radiation and humidity conditions (Bryś \& Bryś 2002), precipitation (Wibig 1999, Styszyńska 2001), and the persistence and thick- 
ness of snow cover (Bednorz 2002, Falarz 2007). Recently, hydrologists' attention is drawn to the effect of the NAO on river runoff. Kaczmarek $(2002,2003)$ has shown NAO to affect the volume of meltwater floods on rivers of Central Europe: in a positive NAO stage the spring floods are generally lower than in a negative stage. Regional differences in the impact of the North Atlantic Oscillation (NAO) on the flow of European rivers were studied by Wrzesiński \& Paluszkiewicz (2011). The authors created a classification of river profiles which made it possible to distinguish seven regions differing in terms of the dependence between streamflow and the intensity of the North Atlantic Oscillation. Investigations have also corroborated the influence of NAO on the Warta discharges (Styszyńska \& Tamulewicz 2004) and the existence of asynchronous relationships between winter NAO indices and the discharges of some Carpathian rivers and the Vistula, on which low-water stages develop in the later months of the year, at the close of summer and in autumn (Limanówka et al. 2002, PociaskKarteczka et al. 2002). An analysis of changes in the hydrological seasons and runoff regime characteristics of rivers in different NAO stages has been made by Wrzesiński (2004, 2005, 2007, 2010b) and Danilovich et al. (2007). On the rivers of Central Europe the sequence of hydrological seasons usually does not change; what changes is the starting date, duration and intensity of a hydrological event occurring in the given period. Spring floods in a negative NAO stage are clearly of greater magnitude, delayed and shorter, while in a positive NAO stage one can observe an earlier start of the low-water season and a higher low-flow runoff, with the duration of low-flow seasons remaining basically unchanged.

The results of the research carried out by Wrzesinski (2008a, b, 2010a) have proved that the oscillation also impacts the forming conditions, volume and seasonality of the runoff of Polish rivers. The greatest impact of the North Atlantic Oscillation intensity can be observed in the runoff during the winter and spring seasons. Usually, a positive correlation can be observed during winter and a negative one during spring. In the winter season, the runoff in the north-eastern and northern parts of the country during the positive NAO stage is twice as high as that observed during the negative stage. The changes in the intensity of the North Atlantic Oscillation contribute to the destabilization of the runoff regime characteristics of Polish rivers (Wrzesiński 2009, Wrzesiński \& Tomaszewski 2010). The observed changes in the stability of the lowest and highest monthly runoff occurrence on the Warta river between 1822 and 2005 clearly corelate with the NAO circulation periods worked out by Marsz (1999). During warmer winters, a higher changeability of discharge during thaw and earlier higher flows can be observed in a positive $\mathrm{NAO}_{\mathrm{DJFM}}$ stage. The aim of this paper is to present the regional differences in the influence of the North Atlantic Oscillation on the seasonal river runoff in Poland.

\section{Methods}

The analysis embraced monthly and seasonal runoff of 146 gauging stations located on 96 Polish rivers, taking into consideration Hurrell's winter NAO index from the years 1951-2000. The selected rivers are distributed evenly throughout Poland and represent a diversity of environmental conditions (Fig. 1).

The change of runoff conditions in Poland during the two NAO stages and their regional diversity was determined based on the runoff volumes in these stages with respect to one another. The monthly and seasonal runoff changes during years of exceptionally high values of the $\mathrm{NAO}_{\mathrm{DIFM}}$ index $\left(\mathrm{NAO}_{\mathrm{DIFM}}>2,0\right)$ were calculated and compared with the runoff during years of exceptionally low values of the $\mathrm{NAO}_{\mathrm{DJFM}}$ index $\left(\mathrm{NAO}_{\mathrm{DJFM}}<\right.$ $-2,0)$. These values correspond with the first and third quartile of the whole $\mathrm{NAO}_{\mathrm{DJFM}}$ index set for the years 1951 - 2000. In order to determine the change of runoff volumes in both $\mathrm{NAO}_{\mathrm{DJFM}}$ stages with respect to each other, an index of change was used:

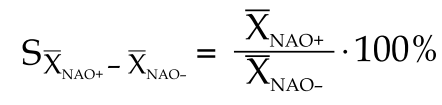

where

$\bar{X}_{\mathrm{NAO}+}, \bar{X}_{\mathrm{NAO}-}$ - average runoff during the positive $(\mathrm{NAO}+)$ or negative (NAO-) $\mathrm{NAO}_{\mathrm{DJFM}}$ stage .

The index of change describes the runoff during the positive $\mathrm{NAO}_{\mathrm{DJFM}}$ stage (in \%), assuming 


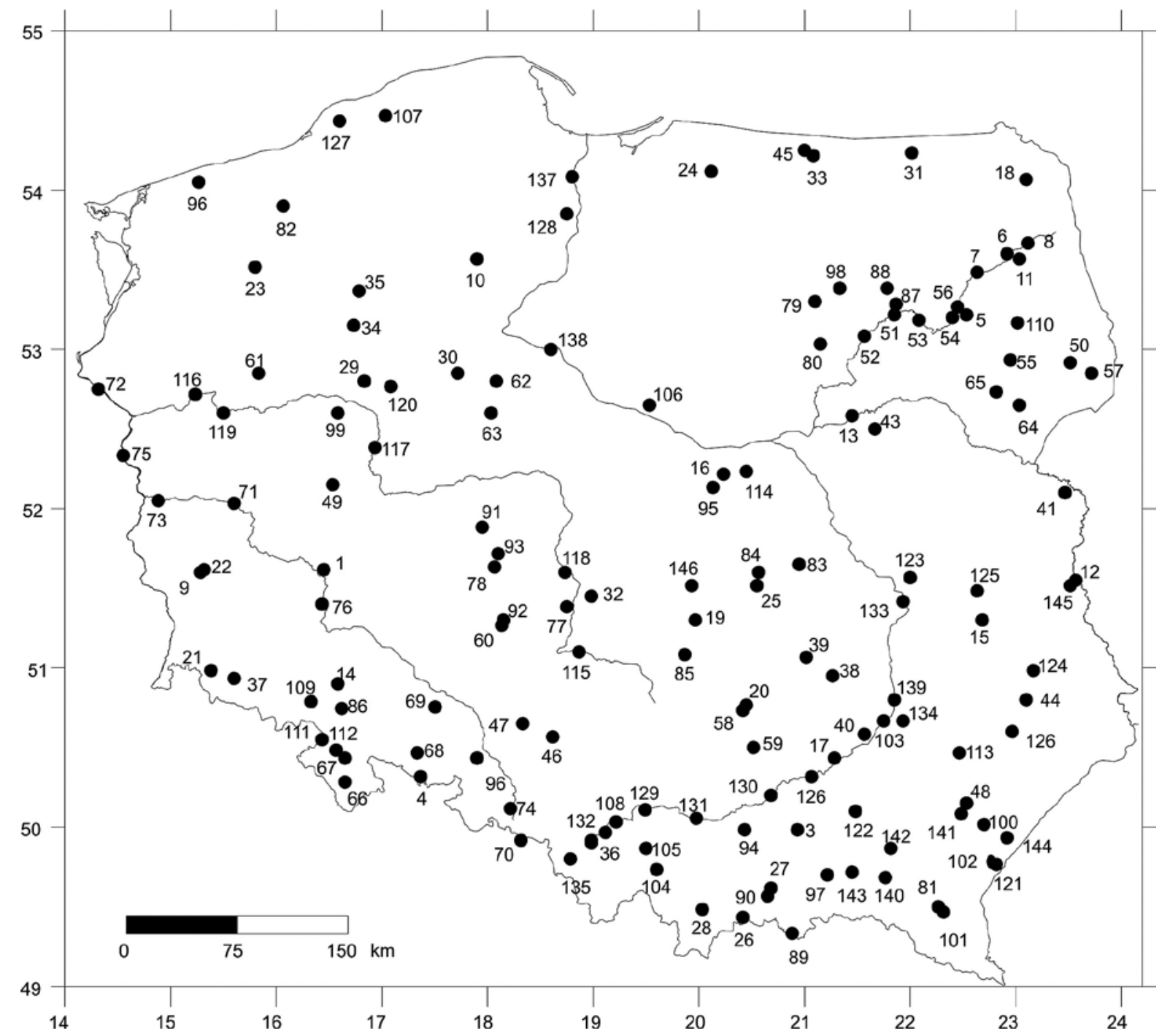

Fig. 1. Location of gauging stations on the rivers under study.

1 - Barycz-Osetno, 2 - Biała-Dobra, 3 - Biała-Koszyce Wielkie, 4 - Biała Głuchołaska -Głuchołazy, 5 - Biebrza-Burzyn, 6 - Biebrza-Dębowo, 7 - Biebrza-Osowiec, 8 - Biebrza-Sztabin, 9 - Bóbr-Żagań, 10 - Brda-Tuchola, 11 - Brzozówka-Karpowicze, 12 - Bug-Włodawa, 13 Bug-Wyszków, 14 - Bystrzyca-Krasków, 15 - Bystrzyca-Sobianowice, 16 - Bzura-Sochaczew, 17 - Czarna-Połaniec, 18 - Czarna HańczaCzerwony Folwark, 19 - Czarna Maleniec-Dąbrowa, 20 - Czarna Nida-Tokarnia, 21 - Czarny Potok-Mirsk, 22 - Czerna Wielka-Żagań, 23 - Drawa-Drawsko Pomorskie, 24 - Drwęca Warmińska-Orneta, 25 - Drzewiczka-Odrzywól, 26 - Dunajec-Krościenko, 27 - Dunajec-Nowy Sącz, 28 - Dunajec-Nowy Targ-Kowaniec, 29 - Flinta-Ryczywół, 30 - Gąsawka-Żnin, 31 - Gołdapa-Banie Mazurskie, 32 - Grabia-Grabno, 33 - Guber-Prosna, 34 - Gwda - Piła, 35 - Gwda-Tusza, 36 - Iłownica-Czechowice-Dziedzice, 37 - Kamienica-Barcinek, 38 - KamiennaKunów, 39 - Kamienna-Wąchock, 40 - Koprzywianka-Koprzywnica, 41 - Krzna-Malowa Góra, 42 - Kwisa-Nowogrodziec, 43 - LiwiecŁochów, 44 - Łabuńka-Krzak, 45 - Łyna-Sepopol, 46 - Mała Panew-Krupski Młyn, 47 - Mała Panew-Staniszcze Wielkie, 48 - MleczkaGorliczyna, 49 - Mogilnica-Konojad, 50 - Narew-Narew, 51 - Narew - Nowogród, 52 - Narew-Ostrołęka, 53 - Narew-Piątnica-Łomża, 54 - Narew-Strẹkowa Góra, 55 - Narew-Suraż, 56 - Narew-Wizna, 57 - Narewka-Narewka, 58 - Nida-Brzegi, 59 - Nida-Pińczów, 60 - Nierób-Kuźnica Skakawska, 61- Noteć-Nowe Drezdenko, 62 - Noteć-Pakość 2, 63 - Noteć-Gębice, 64 - Nurzec-Boćki, 65 - NurzecBrańsk, 66 - Nysa Kłodzka-Bystrzyca Kłodzka, 67 - Nysa Kłodzka-Kłodzko, 68 - Nysa Kłodzka-Nysa, 69 - Nysa Kłodzka-Skorogoszcz, 70 - Odra-Chałupki, 71 - Odra-Cigacice, 72 - Odra-Gozdowie, 73 - Odra-Połocko, 74 - Odra - Racibórz-Miedonia, 75 - Odra-Słubice, 76 - Odra-Ścinawa, 77 - Oleśnica-Niechmirów, 78 - Ołobok-Ołobok, 79 - Omulew-Krukowo, 80 - Orzyc-Krasnosielc, 81 - Osława-Zagórz, 82 - Parsęta-Pychówko, 83 - Pilica -Białobrzegi, 84 - Pilica-Nowe Miasto, 85 - Pilica-Przedbórz, 86 - Piława-Mościsko, 87 - Pisa-Dobrylas,

88 - Pisa-Ptaki, 89 - Poprad-Muszyna, 90 - Poprad-Stary Sącz, 91 - Prosna-Bogusław, 92 - Prosna-Mirków, 93 - Prosna-Piwonice, 94

- Raba-Proszówki, 95 - Rawka-Kęszyce, 96 - Rega-Trzebiatów, 97 - Ropa-Klęczany, 98 - Rozoga-Myszyniec, 99 - Sama-Szamotuły, 100 - San-Jarosław, 101 - San-Lesko, 102 - San-Przemyśl, 103 - San-Radomyśl, 104 - Skawa-Sucha, 105 - Skawa-Wadowice, 106 - Skrwa (Prawa)-Parzeń, 107 - Słupia-Słupsk, 108 - Soła-Oświęcim, 109 - Strzegomka-Łażany, 110 - Supraśl-Fasty, 111 - Ścinawka-Gorzuchów, 112 - Ścinawka-Tłumaczów, 113 - Tanew-Harasiuki, 114 - Utrata-Krupice, 115 - Warta-Działoszyn, 116 - Warta-Gorzów Wielkopolski, 117 - Warta-Poznań, 118 - Warta-Sieradz, 119 - Warta-Skwierzyna, 120 - Wełna-Pruśce, 121 - Wiar-Krówniki, 122 - Wielopolka-Brzeźnica, 123 - Wieprz-Kośmin, 124 - Wieprz-Krasnystaw, 125 - Wieprz-Lubartów, 126 - Wieprz-Zwierzyniec, 127 - Wieprza-Stary Kraków, 128 - Wierzyca-Brody Pomorskie, 129 - Wisła-Goczałkowice, 130 - Wisła-Jagodniki, 131 - Wisła-Jawiszowice, 132 - Wisła-Nowy Bierun, 133 - Wisła-Puławy, 134 - Wisła-Sandomierz, 135 - Wisła-Skoczów, 136 - Wisła-Szczucin, 137 - Wisła-Tczew, 138 - Wisła-Toruń, 139 Wisła-Zawichost, 140 - Wisłok-Krosno, 141 - Wisłok-Tryńcza, 142 - Wisłok-Żarnowa, 143 - Wisłoka-Żółków, 144 - Wisznia-Nienowice, 145 - Włodawka-Okuninka, 146 - Wolbórka-Zawada. 
the runoff during the negative $\mathrm{NAO}_{\mathrm{DJFM}}$ stage to be $100 \%$.

Finally, a classification of the rivers was made in terms of the similarity of deviations of their seasonal runoff between the different $\mathrm{NAO}_{\mathrm{DJFM}}$ stages. In the classification procedure use was made of Ward's method of hierarchical grouping, one of the most popular ways of deriving clusters of similar elements.

During the execution of the research, Surfer 8 [Golden Software] and CorelDRAW 12 [Corel] were used. Moreover, the kriging technique was used in order to create contour maps.

\section{Results}

\section{River runoff in the two NAO stages}

The strong correlations of the runoff of Polish rivers with the winter NAO index (Wrzesiński 2008a) makes it interesting to examine the streamflow and its seasonality (changes in the yearly cycle) in the two NAO stages.

In January and February, higher flows can be observed in most of Poland in a positive NAO stage (Fig. 2). The runoff of rivers in the north eastern region of the country in a positive NAO stage is $150 \%$ to $300 \%$ of that observed in a negative NAO stage. This is also the area where statistically most significant differences (even $\mathrm{p}<0.01$ ) appear between the runoff in the years with a positive $(\mathrm{NAO}+)$ and a negative (NAO-) $\mathrm{NAO}_{\mathrm{D}-}$ JFM index (Wrzesiński 2008a). In the analysed months big flow differences between periods with extreme values of the $\mathrm{NAO}_{\mathrm{DJFM}}$ index also are observed in the case of mountain rivers and those of the Pomeranian Lakeland. In January, on some of the rivers they are statistically significant $(\mathrm{p}<0.05)$, and the runoff in a NAO+ stage is $25 \%$ to $50 \%$ higher than that in a NAO- stage.

In March the situation changes. In northern Poland and the mountains in the south the runoff figures in a NAO+ stage are still higher, but statistically significant differences are only recorded in the north - eastern part of the country $(p<0.01)$. There the river runoff in a NAO+ stage is more than $175 \%$ of that in a NAO - stage. However, rivers of the entire central lowland part of the country and the upland region show higher runoff in a negative NAO stage. It is locally $25 \%$ higher than that in a positive stage, but the observed differences are usually statistically insignificant.

In April, almost in the whole of Poland that rivers show markedly higher runoff figures in the years with negative values of the $\mathrm{NAO}_{\mathrm{DJFM}}$ index. Runoff in a negative stage is $25 \%$ higher than that observed in a positive stage on rivers of the upper and middle Oder and middle Warta basins, in the western part of the Mazurian Lakeland, and the eastern part of the Vistula basin below the mouth of the San, where locally it can be even more than $50 \%$ higher. The rivers of those regions also display the most statistically significant $(p<0.05)$ differences in flows in the two NAO stages.

A similar situation occurs in May, with clearly higher flows in a negative $\mathrm{NAO}_{\mathrm{DJFM}}$ stage observed on rivers in the central and western parts of the country. Flows are then more than $25 \%$ and locally even $50 \%$ higher than in a NAO+ stage. There is also an expansion of the area of statistically significant flow differences $(\mathrm{p}<0.05)$, now covering most of this region with the exception of the central part of the Pomeranian Lakeland and the catchments between the Warta and the Vistula. Though still higher in a negative NAO stage, the runoff decreases in the eastern part of the country, while in the south - east, from the Poprad to the San, higher flows are observed in a positive $\mathrm{NAO}_{\mathrm{DJFM}}$ stage, but the differences are not statistically significant.

In June, on most of the rivers the runoff is still higher in a negative NAO stage, but statistically significant differences are only observed on some rivers in the upper Warta and Noteć basins. On lakeland rivers and those in the upper part of the Wisłoka system, slightly higher flows are recorded in a positive NAO stage. A similar situation also occurs in the next months (VII-IX): flows are still higher in a negative NAO stage, but a growing area in the east of the country is characterised by higher flows in a positive stage. Also, no statistically significant differences are noted between flows in the two NAO stages. From November, an increasingly bigger region in the north and east of the country, and in December also the catchments of the Sudeten and the Silesian Beskids, show higher runoff figures in a positive NAO stage. Statistically significant 

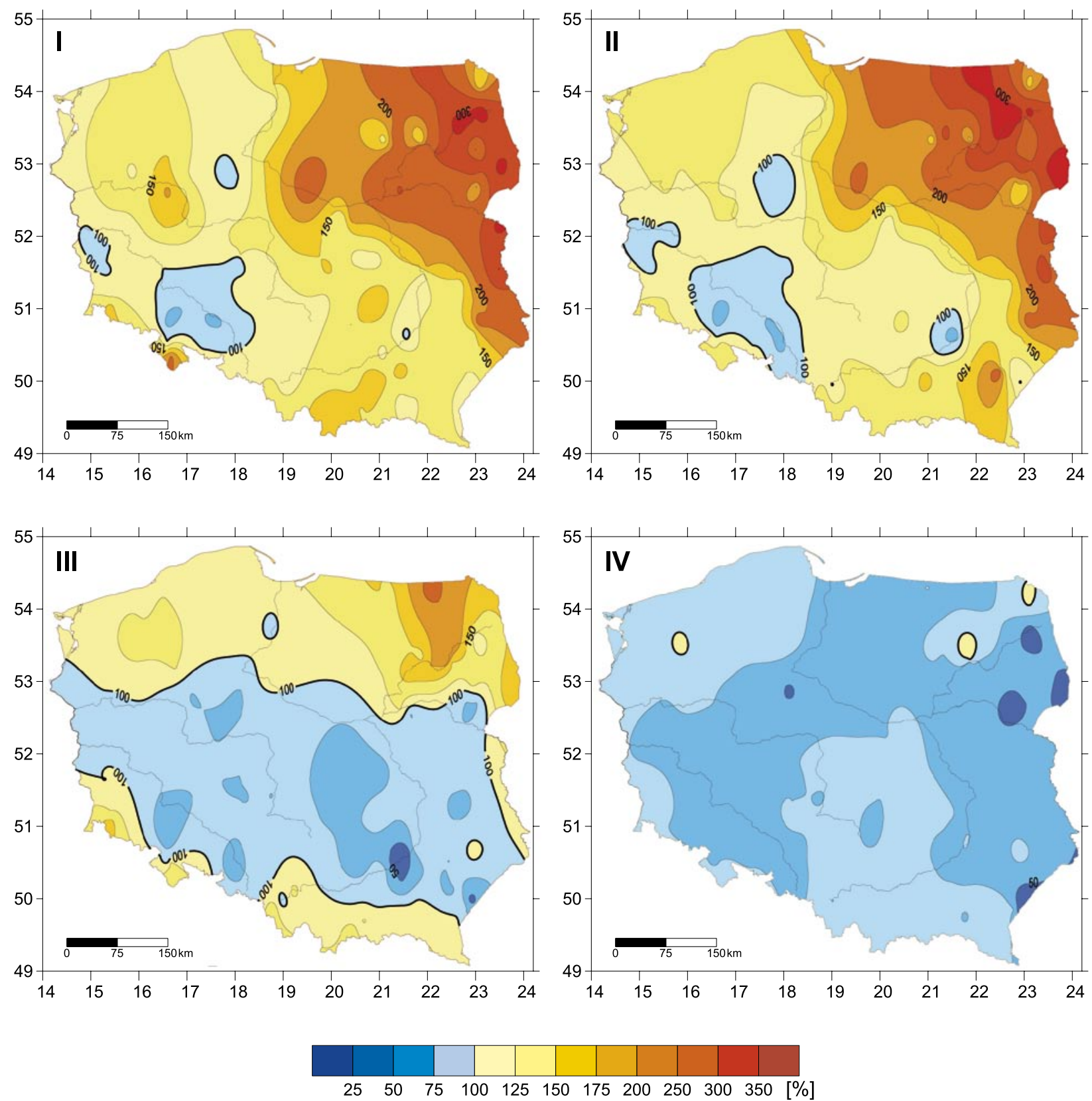

Fig. 2. Deviations of monthly flows (in \%) in the different NAO stages (the $\mathrm{H}_{\mathrm{NAO}-}=100 \%$ ), the Latin numbers designate the months respectively.

differences $(\mathrm{p}<0.05)$ in the flows, observed in the two NAO stages, are only recorded on rivers of the Biebrza basin.

\section{Seasonal flows}

Similar regularities are observed when analysing seasonal flows in the two $\mathrm{NAO}_{\text {DJFM }}$ stages. In winter (mean runoff of the months XII - II) decidedly higher flows are observed on most of the
Polish rivers in a positive NAO stage (Fig. 3). In the north - east they are then twice or three times higher than in a NAO- stage, and the observed differences are highly significant statistically $(\mathrm{p}<0.001)$ (Wrzesiński 2008a). Only some rivers of the upper and middle Oder basin and the upper Noteć basin display higher flows in a negative NAO stage, but the differences are small and statistically insignificant.

On most of the Polish rivers, spring and summer flows have higher values in a negative 

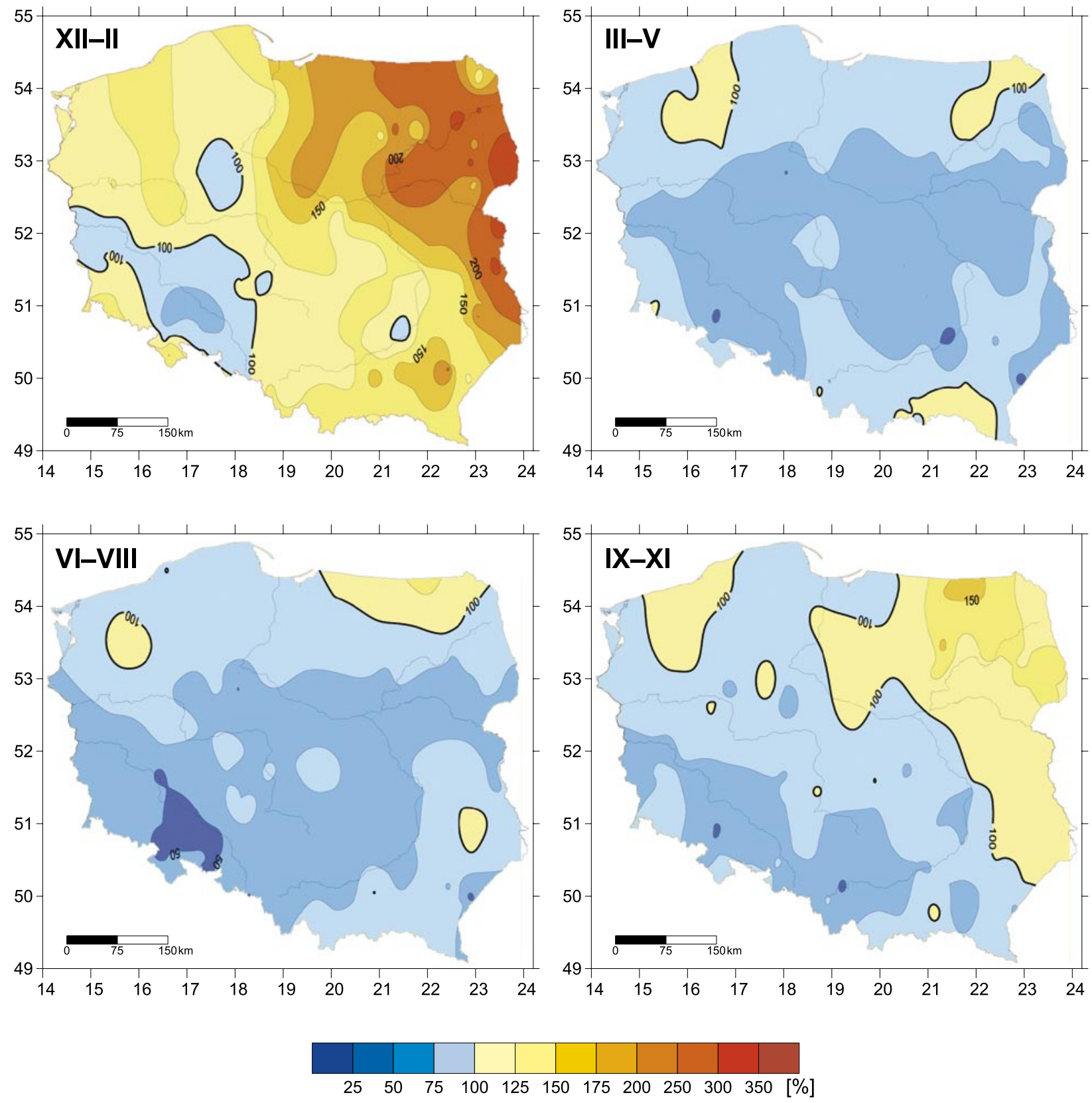

Fig. 3. Deviations of seasonal flows (in \%) in the different NAO stages (the $\mathrm{H}_{\mathrm{NAO}-}=100 \%$ ).

$\mathrm{NAO}_{\text {DIFM }}$ stage. Flows observed in this stage exceed those in a positive stage, especially in the central part of the country, by $25 \%$ to $50 \%$. However, statistically significant differences $(p<0.05)$ are recorded for only some of the rivers of the upper and middle parts of the Oder basin. There are a few lakeland rivers with a runoff greater in a positive NAO stage in those seasons, but the observed differences are not statistically significant.

In autumn (IX-XI) there is a clear increase in the area of the country, mostly east of the Vistula and the central part of the Pomeranian Lakeland, in which higher flows are observed in a positive $\mathrm{NAO}_{\text {DIFM }}$ stage. Locally, in the north - eastern part of the country the flows can then be even $50 \%$ higher than those in a negative stage, but the observed differences are not statistically significant. In the remaining area the flows in a negative stage exceed those in a positive stage, but again the observed differences are not statistically significant. 


\section{Classification of rivers in terms of the value of seasonal deviations of flows between a positive and a negative $\mathrm{NAO}_{\mathrm{DJFM}}$ stage}

Classification of the rivers was made in terms of the similarity of deviations of their seasonal runoff between the different $\mathrm{NAO}_{\mathrm{DJFM}}$ stages. The results of grouping were presented graphically in the form of a dendrogram; it reflected the structure of similarity of the set of objects under study and could serve as a basis for distinguishing typological classes (Fig. 4). Each grouping level yields a different number of clusters of similar units. The lower the level, the higher the similarity of units within a cluster. As the linking distance increases, the within - cluster linkage of elements weakens. Establishing an optimum number of classes is a procedure important for the choice of the best variant of classification, but difficult because of a lack of an objective method. In the paper, the number of classes was established on the basis of the geometry of the dendrogram and the curve of the linkage distance. In this way, five classes (groups) of the river profiles under analysis were obtained.

To characterise the impact of the NAO on streamflow in each region and identify differences among the regions, diagrams of deviations of seasonal runoff were plotted for each of them (Fig. 5).

Five groups of rivers were distinguished on the basis of the similarity of deviations of their seasonal runoff between the different $\mathrm{NAO}_{\mathrm{DJFM}}$ stages.

Group 1 embraces rivers flowing in the north - eastern part of Poland (the Guber, Gołdapa, Biebrza, upper Narew, and Krzna). They are characterised by winter flows that are decidedly higher, $160 \%$ on average, in a positive NAO stage than in a negative one. Also higher in a positive NAO

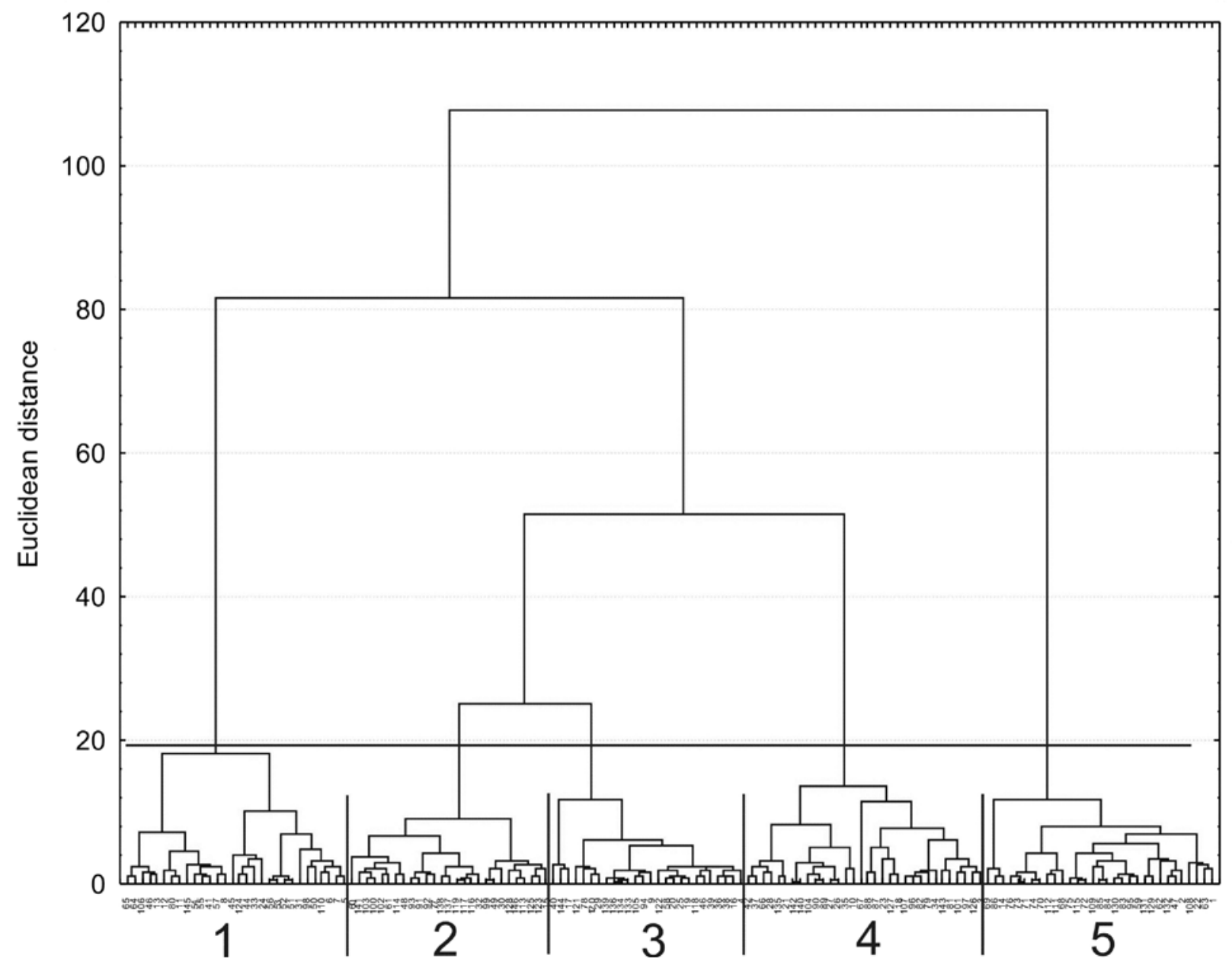

Fig. 4. River grouping dendrogram - Ward's method. Classification of rivers based on deviations of seasonal runoff between the different $\mathrm{NAO}_{\mathrm{DIFM}}$ stages. 


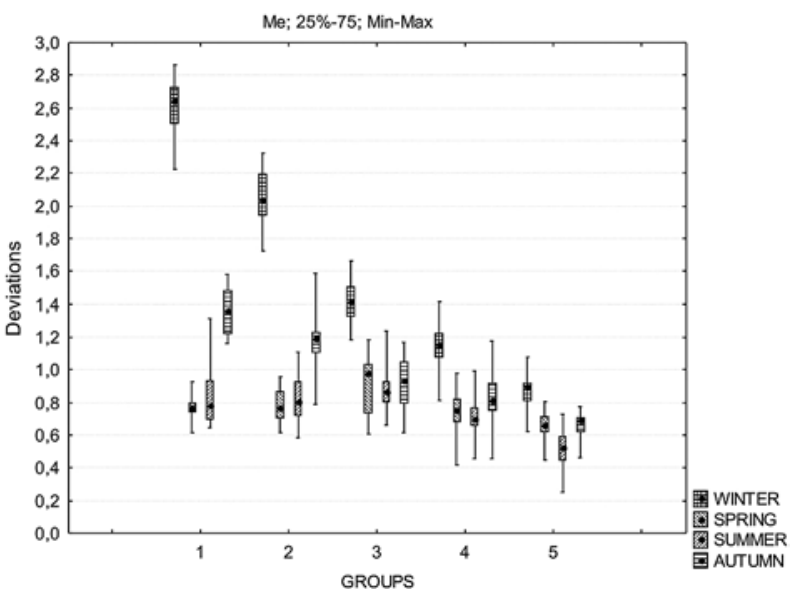

Fig. 5. Differences in the deviations of seasonal flows between a positive and a negative $\mathrm{NAO}_{\mathrm{DJFM}}$ stage in the river groups.

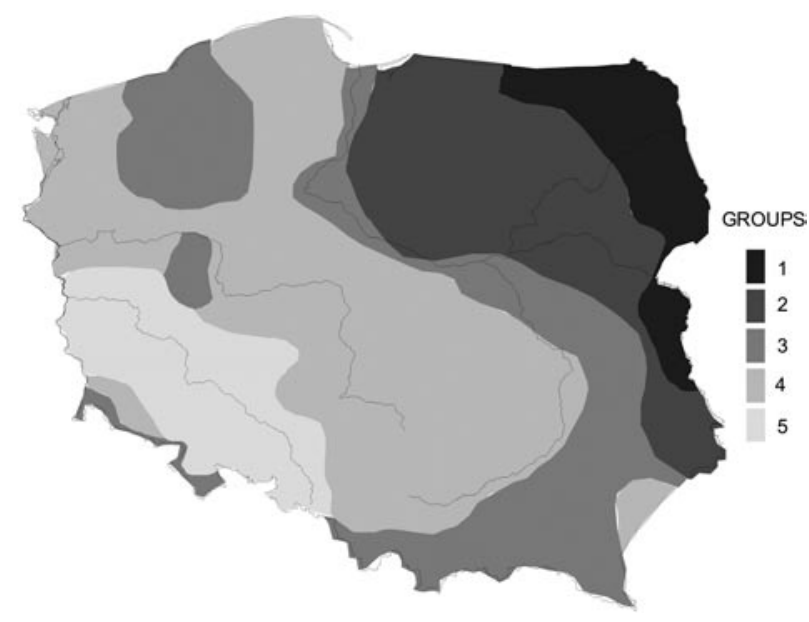

Fig. 6. Typological classes of rivers distinguished on the basis of the similarity of deviations of their seasonal runoff between the different $\mathrm{NAO}_{\mathrm{DJFM}}$ stages.

stage are autumn flows, $40 \%$ on average. In turn, spring and summer flows are lower in this stage and constitute about $80 \%$ of the runoff observed in a negative NAO stage (Fig. 6).

Group 2 includes the rivers of the Mazurian Lakeland, middle parts of the Narew and Bug basins, and the upper Wieprz basin. The nature of the relationships of the seasonal flows of those rivers in the two NAO stages is similar to those observed in the rivers of group 1. Winter and autumn flow figures in a positive NAO stage are again higher than those recorded in a negative one, but not so markedly $-100 \%$ and $20 \%$, respectively.

Group 3 embraces rivers of the upper Vistula basin (the Carpathian tributaries), the Sudeten, rivers of the middle Vistula basin (the Wieprz,
Utrata, Vistula below the mouth of the Wieprz), and those of the central part of the Pomeranian Lakeland. In a positive NAO stage flows on those rivers in the winter season are on average $40 \%$ higher. Flows in the remaining seasons are as a rule higher in a negative stage. The smallest differences are observed in the spring runoff, with mountain and lakeland rivers showing then slightly higher flows, $5 \%$ on average, in a positive NAO stage. Flows in the summer and autumn seasons are about $10 \%$ higher in a negative stage.

Group 4 embraces rivers of a large part of the country west of the Vistula, with the exception of the upper and middle parts of the Oder basin and the rivers of the Pomeranian Lakeland classified in group 3. Their winter runoff is also higher in a positive NAO stage, $20 \%$ on average. In the remaining seasons, higher flows are observed in a negative stage: in spring $25 \%$, in summer $30 \%$, and in autumn $20 \%$.

Group 5 includes the rivers of the upper and middle Oder basin (with the exception of its mountain sections). In a negative NAO stage, higher flows are observed in all the seasons - 10\% on average in winter, $30 \%$ in spring and autumn, and even $50 \%$ in summer.

\section{Conclusions}

The research results have confirmed a strong effect of the North Atlantic Oscillation on the runoff volume of the Polish rivers. The obtained results show that the North Atlantic Oscillation has the greatest effect on streamflow in the winter - spring months, i.e. in the period when the most abundant water resources are being formed in Poland. Hence, in a positive NAO stage, one might expect a considerable buildup of the water resources in the winter months, mostly in the north - east, and their marked dwindling almost throughout the entire country in spring. The diversity of environmental conditions in the catchments of the analysed rivers gives the observed relationships a different character, which was confirmed by the typological classification of the rivers by deviations of their seasonal flows in a positive and a negative $\mathrm{NAO}_{\mathrm{DJFM}}$ stage. The results of the grouping made it possible to dis- 
tinguish five regions in Poland differing in the values of seasonal flows observed in the years with extreme winter values of the NAO index. This division is strongly influenced by the environmental conditions in the catchments, mainly climatic conditions which determine the beginning of thaw, seasonality and volumes of runoff. The spatial differences in the impact of the North Atlantic Oscillation clearly corelate with the regional hydrological regime divisions of rivers in Poland.

\section{References}

BRYŚ K. \& BRYŚ T., 2002. Wpływ Oscylacji Północnoatlantyckiej na zmienność warunków wilgotnościowych, radiacyjnych, dynamicznych i ewaporacyjnych we Wrocławiu-Swojcu w latach 1946-2000. In: A. Marsz, A. Styszyńska (eds.), Oscylacja Pótnocnego Atlantyku i jej rola w ksztattowaniu zmienności warunków klimatycznych $i$ hydrologicznych Polski. Akademia Morska w Gdyni: $147-160$

BEDNORZ E., 2002. Snow cover in western Poland and macroscale circulation conditions. International Journal of Climatology 22: 533-541.

DANILOVICH I., WrZEsińSKI D. \& NeKRASOva L., 2007. Impact of the North Atlantic Oscillation on river runoff in the Belarus part of the Baltic Sea basin. Nordic Hydrology 38(4-5): 413-423.

FALARz M., 2007. Snow cover variability in Poland in relation to the macro- and mesoscale atmospheric circulation in the twentieth century. International Journal of Climatology 27: 2069-2081.

KaczMareK Z., 2002. Wpływ Oscylacji Północnoatlantyckiej na przepływy rzek europejskich. In: A. Marsz, A. Styszyńska (eds.), Oscylacja Pótnocnego Atlantyku i jej rola w ksztattowaniu zmienności warunków klimatycznych $i$ hydrologicznych Polski. Akademia Morska w Gdyni: 163-172.

KACZMAREK Z., 2003. The Impact Climate Variability on Flood Risk in Poland. Risk Analysis 23: 559-566.

Kożuchowski K. \& DeGiRmendžić J., 2002. Wskaźniki cyrkulacji a temperatura powietrza w Polsce. In: A. Marsz, A. Styszyńska (eds.), Oscylacja Pótnocnego Atlantyku i jej rola w ksztattowaniu zmienności warunków klimatycznych $i$ hydrologicznych Polski. Akademia Morska w Gdyni: 111-128.

LimanóWKa D., Nieckarz Z. \& Pociask-KarteczKa J., 2002. The North Atlantic Oscillation impact on hydrological regime in Polish Carpathians. Interdisciplinary Approaches in Small Catchment Hydrology: Monitoring and Research, FRIEND International Conference, Demanovska Dolina: 132-135.

Marsz A., 1999. Oscylacja Północnoatlantycka a reżim termiczny zim na obszarze północno-zachodniej Polski i na polskim wybrzeżu Bałtyku (The North Atlantic Oscillation and the thermal regime in the area of north-west Poland and the Polish coast of the Baltic sea). Przeglad Geograficzny 71, 3: 225-245.

Marsz A., 2001. Stan termiczny Pótnocnego Atlantyku a reżim termiczny zim na polskim wybrzeżu Battyku (problem dtugo- terminowej prognozy termiki zim). Wyższa Szkoła Morska w Gdyni.

Marsz A. \& Styszyńska A., 2001. Oscylacja Pótnocnego Atlantyku a temperatura powietrza nad Polska (The North Atlantic Oscillation and the Air Temperature over Poland). Wyższa Szkoła Morska w Gdyni.

MARSZ A. \& ŻMUdZKA E., 1999. Oscylacja Północnego Atlantyku a długość okresu wegetacyjnego w Polsce (The North Atlantic Oscillation and the lenght of a vegetative period in Poland). Przegl. Geofiz. 44, 4: 199-210.

NiedźwIEDź T., 2002. Relacje między NAO a wskaźnikami cyrkulacji nad Polską. In: A. Marsz, A. Styszyńska (eds.), Oscylacja Pótnocnego Atlantyku i jej rola w kształtowaniu zmienności warunków klimatycznych i hydrologicznych Polski. Akademia Morska w Gdyni: 87-97

Pociask-KarteczKa J., LimanówKa D. \& Nieckarz Z., 20022003. Wpływ oscylacji północnoatlantyckiej na przepływy rzek karpackich (1951-2000) (The North Atlantic Oscillation impact on hydrological regime In Polish Carpathians (1951-2000). Folia Geographica, series Geographica Physica 33-34: 89-104.

Przybylak R., Wójcik G. \& Marciniak K., 2003. Wpływ Oscylacji Północnoatlantyckiej i Arktycznej na warunki termiczne chłodnej pory roku w Polsce w XVI-XX wiekach (Influence of the North Atlantic Oscillation and Arctic Oscillation on thermal conditions in the cold season In Poland from the $16^{\text {th }}$ to the $20^{\text {th }}$ centuries). Przegl. Geofiz. 48: 61-74.

StYSZYŃSKa A., 2001. Oscylacja Północnego Atlantyku a opady na obszarze Polski. Prace i Studia Geograficzne 29: 232-241.

StYSZYŃSKA A. \& TAMULEWicZ J., 2004. Warta river discharges in Poznań and atmospheric circulation in the North Atlantic region. Quaestiones Geographicae 23: 63-81.

WiBIG J., 1999. Precipitation in Europe in relation to circulation patterns at the $500 \mathrm{hPa}$ level. International Journal of Climatology 19: 253-269.

WRZESIŃSKI D., 2004. Flow regimes of rivers of northern and central Europe in various circulation periods of the North Atlantic Oscillation (NAO). XXIII Nordic Hydrological Conference, NHP Report 48, Tallinn: 670-679.

WRZESIŃSKI D., 2005. Changes of the hydrological regime of rivers of northern and central Europe in various circulation periods of the North Atlantic Oscillation. Quaestiones Geographicae 24: 97-109.

WRZESINSSKI D., 2007. Impact of the North Atlantic Oscillation on features of the hydrological regimes in Europe. Proceedings The Third International Conference on Climate and Water. Finnish Environment Institute SYKE, Helsinki: 538-543.

WrZESIŃSKI D., 2008a. Impact of the North Atlantic Oscillation on river runoff in Poland. IWRA $13^{\text {th }}$ World Water Congress Montpellier, France, 1-4 September 2008 (http:// wwc2008.msem.univ - montp2.fr/resource/authors/ abs217_article.pdf).

WRZESIŃSKI D., 2008b. Typology of spatial patterns seasonality in European rivers flow regime. Quaestiones Geographicae 27A/1: 87-98.

WrZESIŃSKi D., 2009. Stabilność reżimu odpływu rzek w Polsce (Stability of the river flow regime in Poland). In: A. Jankowski, D. Absalon, R. Machowski, M. Ruman (eds.), Przeobrażenia stosunków wodnych w warunkach zmieniającego się środowiska. Sosnowiec: 307-318.

WrZESIŃSKI D., 2010a. Odpływ rzek w Polsce w różnych fazach Oscylacji Północnoatlantyckiej (River runoff in Po- 
land in different stages of the North Atlantic Oscillation). Bad. Fizjogr. nad Pol. Zach. R. I, A(A61): 129-144.

WRZESIŃSKI D., 2010b. Przestrzenne zróżnicowanie stabilności rezimu odptywu rzek europejskich (Spatial differentiation of the stability of the flow regime of European rivers). Bogucki Wydawnictwo Naukowe, Studia i Prace z Geografii i Geologii 3, Poznań.

WrZESIŃSKI D. \& PALUSZKIEWICZ R., 2011. Spatial differences in the impact of the North Atlantic Oscillation on the flow of rivers in Europe. Hydrology Research 42, 1: 30-39.
WrZesiński D. \& ToMAsZEWSKi P., 2010. Stabilność elementów hydrometeorologicznych w Polsce w latach 1951-2000 (Stability of hydrometeorological elements in Poland in the years 1951-2000). In: D. Wrzesiński (ed.), Odptyw rzeczny i jego regionalne uwarunkowania. Bogucki Wydawnictwo Naukowe, Poznań: 169-185. 